\title{
FORMATION OF ECOLOGICAL CULTURE AND EDUCATION THROUGH PHOTOGRAPHY
}

\author{
Tashmukhamedova Gulnora Khudayberdievna ${ }^{1}$ \\ ${ }^{1}$ Senior Lecturer of the Department of Systems and Applications of TV Studios, Tashkent University of Information \\ Technologies named after Muhammad al-Khorezmi \\ Bazarbayev Batyr Zholdasovich ${ }^{2}$ \\ ${ }^{2}$ Senior Lecturer of the Department of Systems and Applications of Television Studios, Tashkent University of \\ Information Technologies named after Muhammad al-Khorezmi \\ Azamat-Akhunova Nozima ${ }^{3}$ \\ ${ }^{3} 4$ th year student of the Tashkent University of Information Technologies named after Muhammad al-Khorezmi
}

Annotation. Issues related to environmental pollution are considered. It is shown that the root cause of this phenomenon is the lack of environmental culture and education in people. It is proposed by means of photography to influence the consciousness of the public and, through emotions, cause an appropriate reaction in people and give them an impulse to assess their attitude to nature.

Keywords. ecological culture and education, environmental pollution, eco-photography, photographic art, ecological problem, ecological crisis, visual purity of space, visual language

\section{Introduction}

The speed at which civilization is developing, and therefore the speed at which humans are devastating our amazingly beautiful planet, is growing month after month. "Everyone's duty is to try to prevent the terrible desecration of our world, and everyone can make their own, albeit small, albeit modest contribution to this struggle." (J. Darrell Gerald (English zoologist, animalist writer, conservationist and animal advocate)) [1].

Since the beginning of the 20th century, environmental issues have become relevant in most countries of the world. Despite the fact that during the quarantine period, human influence on nature has significantly decreased, it cannot be said that the global ecosystem is safe.

Activists from different countries draw public attention to the eco-problems of their regions, often choosing non-standard methods for this. Artists, sculptors, writers, with the help of their works, try to convey to the public the idea that if decisive action is not taken to save nature now, then there will be nothing to save in the future. Photographers made an important contribution to the preservation of the natural environment.

\section{Main part}

Photo contests on eco photography are held annually in the world. Eco-photography is a direction in photography that seeks to show the ecological environment of our planet as a whole. beautiful places, mesmerizing landscapes and, of course, nature photography that has a deep meaning are the mainstays of this trend.

In 2019, the English charity CIWEM announced the winners of the Environmental Photographer 2019, which featured works from all over the world.

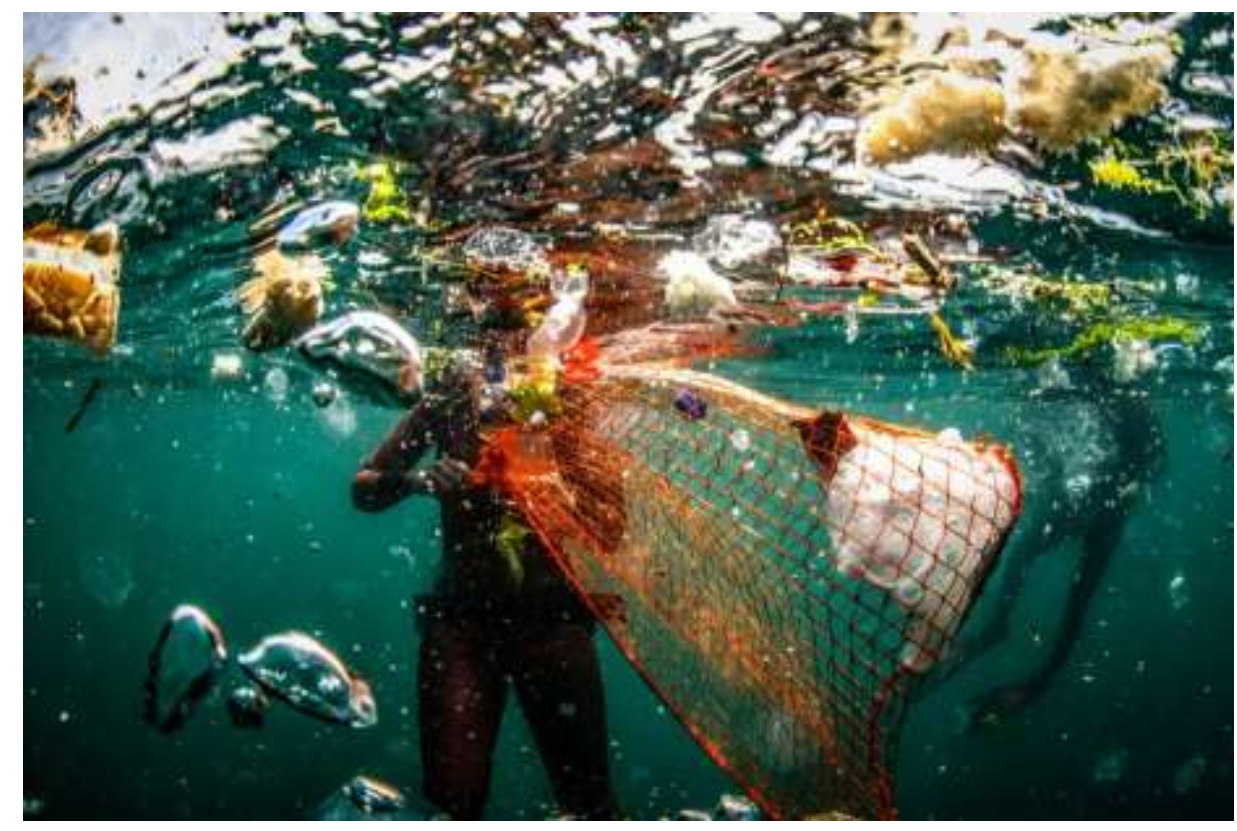


"Trash", Sebnem Coskun, Turkey. Underwater treatment on the Bosphorus within the Zero Waste Blue project.

The picture shows how human waste is harmful to the environment. Zero Waste (or "Zero Waste") is a social movement whose main goal is to reduce waste as much as possible. This approach helps not only to contain the proliferation of landfills and landfills, reduce resource consumption, but also reduce the amount of trash and unnecessary things in your own living space. [3].

Formulation of the problem. Photography stops time and is a unique form of data recording, in which the existence of certain facts about culture is objectively confirmed, and socio-cultural reality is perceived as it is. At the same time, it should be noted that this direction has another goal: to show the viewer the biggest problem at the moment - the Environmental one. Because a change in the natural environment, as a result of anthropogenic influences or natural disasters, leads to a violation of the structure and functioning of nature itself. The ecological system and the attitude of human society to nature is characterized, in particular, by the fact that a person, society and the state are unable to reverse the tendency of the deterioration of the state of the environment and it is this situation that the photographer should be able to show in his works.

Lack of ecological culture and education is the root cause of the problems associated with environmental pollution. Only an ecologically educated population will be willing to meet and use new eco-technologies. By means of photography, you can influence the consciousness of the public through emotions, evoke an emotional reaction in people and give them an impulse to assess their own attitude to nature.

It is not only demonstrations and protests that can draw public attention to environmental problems. The purpose of this work is to show, in the language of photography, the possibility of bringing an existing environmental problem to the attention of society, etc.

Solution to the problem. The most important global environmental problems facing modern man are the following: environmental pollution, - the greenhouse effect, - depletion of the "ozone layer", - photochemical smog, - acid rain, - soil degradation, deforestation, - desertification, - waste problems, - reduction gene pool of the biosphere, etc. When a photographer starts his work photographing all these problems that surround nature to this day, he helps to pay attention to these seemingly imperceptible problems, which in consequence can become a disaster in the future.

Environmental Photographer of the Year (CIWEM), an international photography competition designed to address environmental and social concerns, is open to all photographers and welcomes photographs that are contemporary, creative and resonant, but above all that inspire people around the world to care for our environment [4].

The Highly Commended winner of the Environmental Photographer of the Year 2018 competition, Floating life on river under pollution by Indian photographer Tapan Karmakar [4] shows how water surfaces are polluted (below).

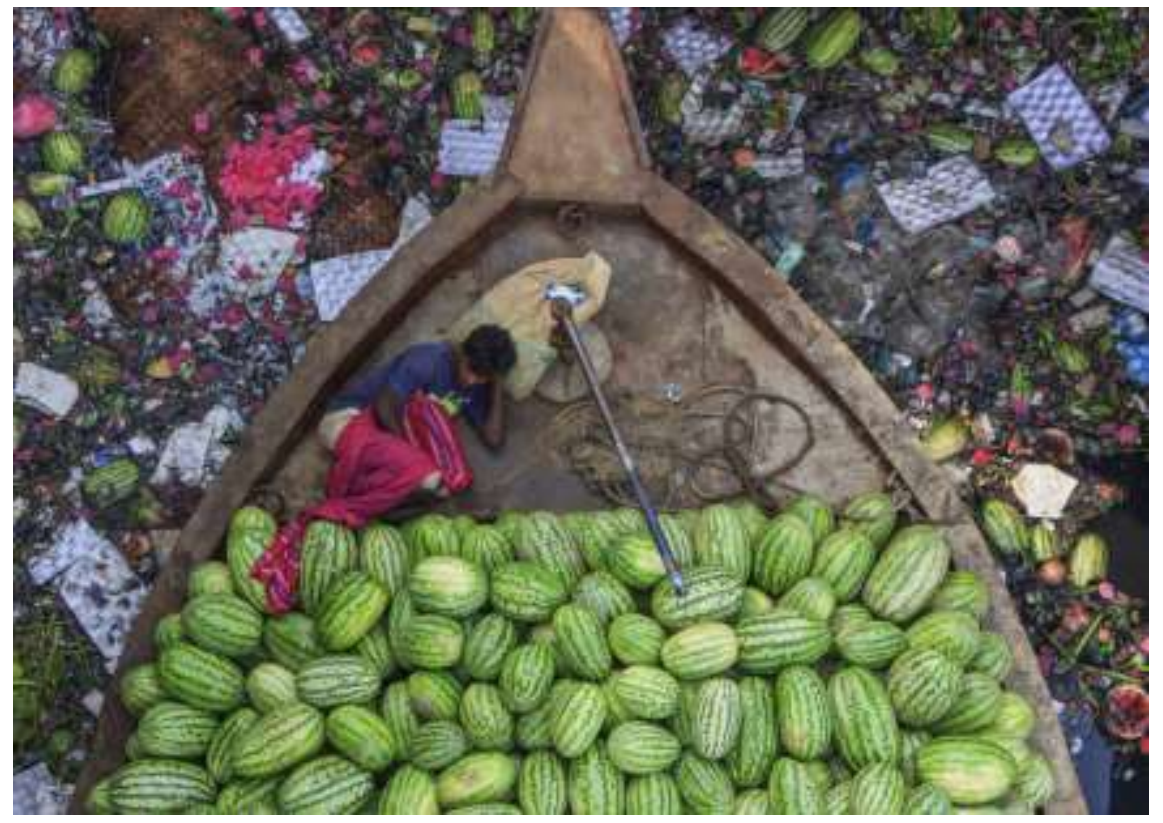

Photography has proven over the course of its history that, like any other language, it is multifunctional. All existing examples of photography are certainly not works of art, but with the help of photography an object of art can be created, just as a language message can be a record of testimony or a work of literature. 
Photography should not only be beautiful from an artistic point of view, it should bring subjective new things to the world, strive to change someone's values and, of course, be the result of purposeful efforts [5].

Photography is inherently sustainable. Just as environmentalists fight for the cleanliness and harmlessness of the environment, photographers defend the visual purity of the space around us. The search for beautiful subjects resembles a hunt for endangered species of animals in order to preserve them, and on the basis of the frames obtained, one can safely form a "Visual Museum of Rare World Moments" [6]. Photography is capable of not only demonstrating the consequences of ecological catastrophes that have already taken place, but also "fantasizing", simulating a variety of future scenarios. What future would you like to live in? What can be done now to get closer to a quality ecology? What is valuable in the world that you would never want to lose? [7]

The French philosopher contributed to the development of visual research. R. Barth. His essay "Camera lucida" (1980) is devoted to the study of the phenomenon of photography, in which he concentrates on the peculiarities of the artistic language of photography and his personal impressions arising from interaction with them. R. Barthes suggests considering photography as a system consisting of two abstract concepts studium and punctum. Studium is interpreted by Bart as a kind of cultural basis that allows the viewer to understand and in a certain way interpret what is depicted in the photograph. Punktum is understood by the researcher as "the incident that ... hurts me, hits me ..." [7], that is, something personal for the contemplator, which attracts his gaze and makes him feel closer to photography. Photography, according to Bart, is not only a social phenomenon, but also an object that causes individual experiences [8].

Photos of garbage dumps, untidy beggars and a littered landscape that have suffered as a result of rash actions of people do not cause positive emotions to anyone. At the same time, photographers should be treated with respect primarily because they perform an important social function - they find problem areas in visual ecology. By the way, this trend has existed for a long time and can affect not only the problems of architecture harmonious for the human eye, but any phenomena that are uncomfortable for the eyes, such as: obtrusive advertising in the middle of a movie, overflowing trash cans in the courtyard and excessively bright lights in a subway car.

Environmental illiteracy can manifest itself not only in not cleaning up garbage in the forest after eating kebabs and drinking abundant fiery water, but also in not trying to change the visual series that surrounds.

Leaving trash behind is tantamount to not noticing a rickety fence and potholes on the roads. Waste thrown out on the streets, unauthorized dumps, irrigation ditches, in which instead of cool water, plastic garbage - all this does not make our cities and residents cultured and educated.
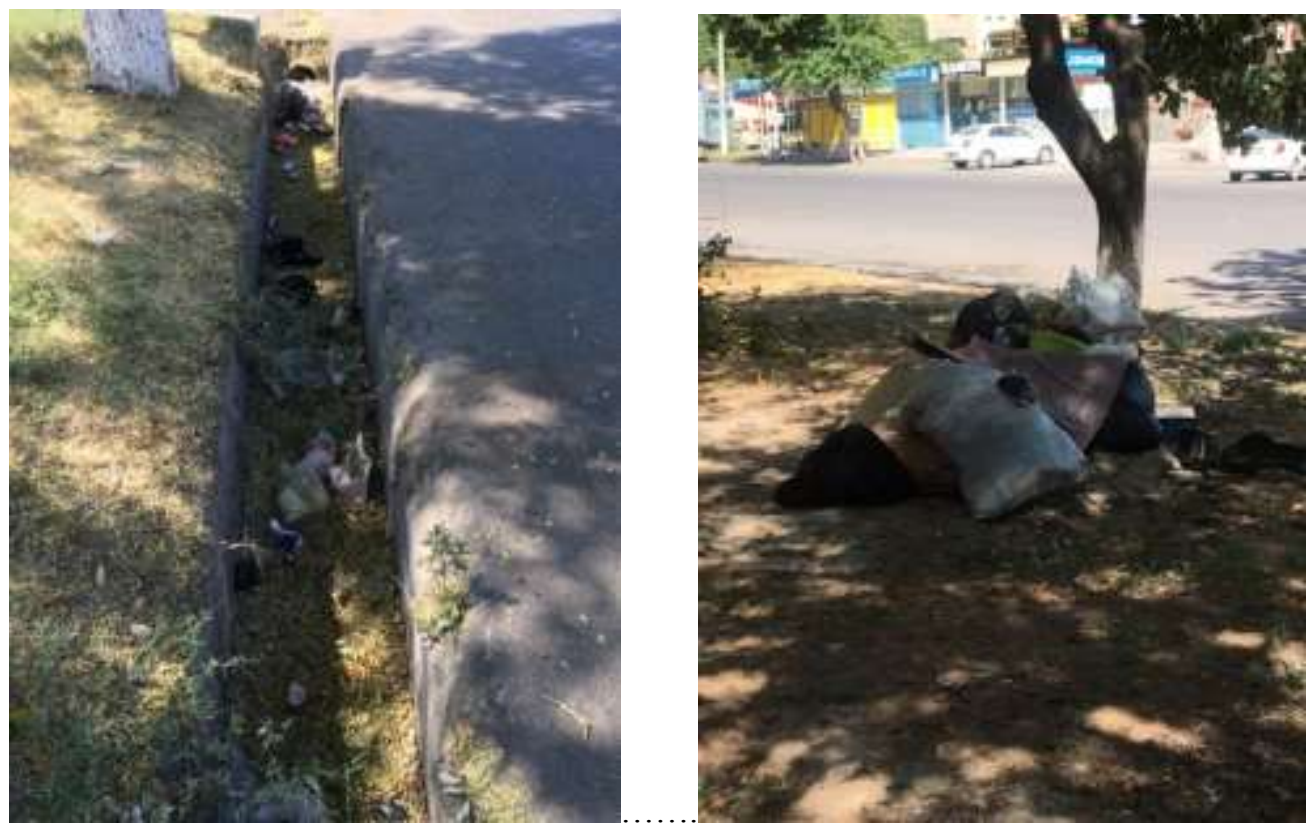

I will give a small example: these photos were taken near the Korzinka supermarket (Tashkent, Yunusabad). When leaving the supermarket, there is a trash can for used gloves, but some visitors ignore and pass by, and throw away used gloves wherever they have to. 


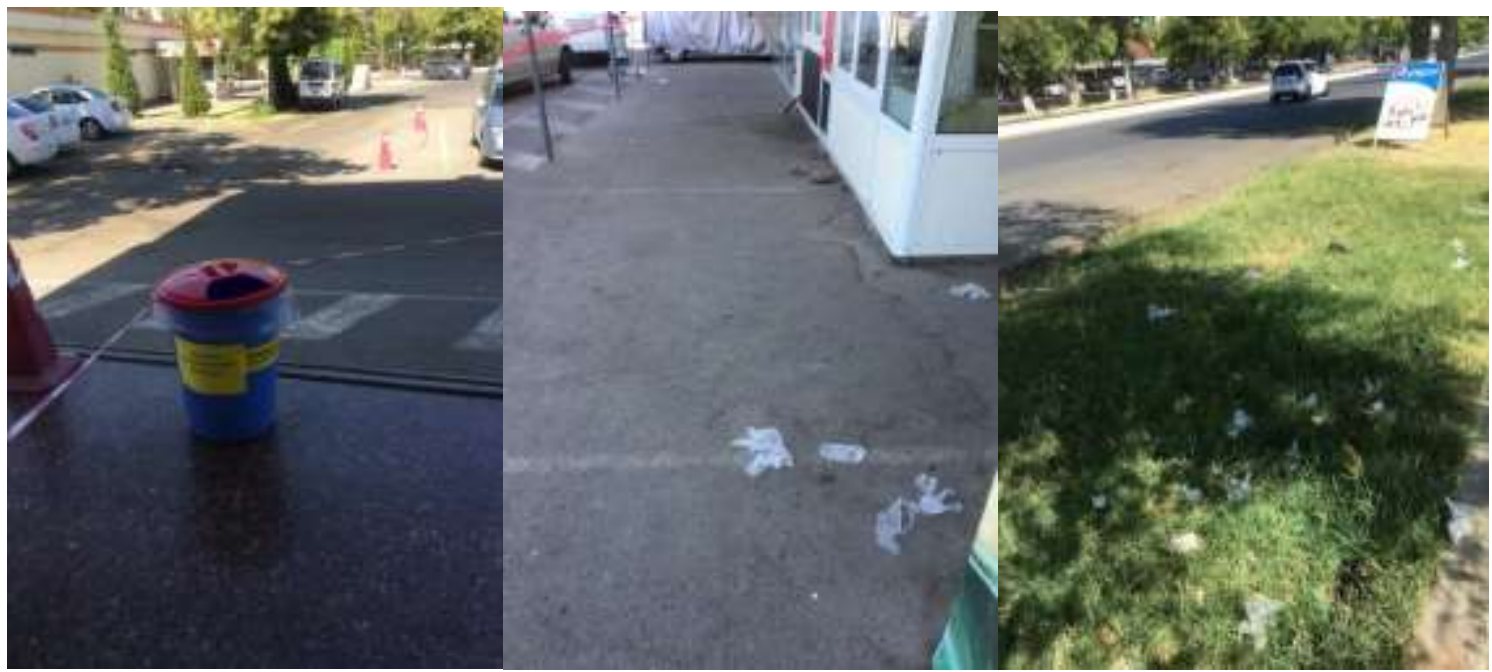

The underdevelopment of ecological culture and education among the majority of our contemporaries. The photo is only a consequence of this and a good indicator of the state - we must fight against the cause. When teenagers look at a smartphone in a subway car, they protest against an unwanted visual environment. It's like putting on a gas mask at a chemical plant. Take it off and suffocate. The same good medical principle works here: the main thing is not treatment, but prevention. There is no need to litter, and the visual landscape needs to be littered.

At the same time, it cannot be denied that our visual environment has seriously changed in recent years, and this is especially true for large cities, in which we live and observe every day. And if humanity realizes the irreparable damage that it causes to the environment, then in the future (at least in the same city) we will be surrounded by an amazingly beautiful picture.

Our task is for people to protect nature. Not only the future of our children depends on this, but also the future existence of our planet as a whole. And to make our future look brighter, we need to pay more attention to the environment and help it recover from the damage.

1. do not litter yourself;

2. not let others litter;

3. to protest against factories and enterprises, polluting the environment;

4. protect animals.

There can be countless such items. The main thing is for people to understand for themselves that nature must be protected and protected.

\section{Conclusion}

Summing up, it should be noted that the formation of a conscious respect for the natural world around a person should be instilled in every person literally from birth. After all, only by drawing people's attention to environmental problems and the values of sustainable development can we increase the efficiency of natural resources use. In this process, appropriate photographs can help. Contemporary creative and resonant photography will help inspire people around the world to care for the environment

To combat environmental pollution, it is necessary to carry out activities to develop environmental culture and education in modern society, especially among the younger generation. To do this, to conduct trainings and photo exhibitions, education in the family is of great importance.

\section{References}

1. $\quad$ https://ekovestnik.wordpress.com/\%D1\%86\%D0\%B8\%D1\%82\%D0\%B0\%D1\%82\%D1\%8B-\%D0\%BE\%D0\%BF\%D1\%80\%D0\%B8\%D1\%80\%D0\%BE\%D0\%B4\%D0\%B5/

2. https://the-steppe.com/gorod/konkurs-eko-fotografii-environmental-photographer-2019-obyavilpobediteley

3. https://trends.rbc.ru/trends/green/5d6bf09d9a7947a2afc38cc0

4. https://az.sputniknews.ru/photo/20180928/417227365/environmental-photographer-of-the-year-2018pobediteli.html

5. Tashmukhamedova Gulnora Khudaiberdievna "Actual trends in modern creative photography". World Scientific News an International Scientific Journal. Poland. WSN № 119 (2019). Date of Publication 27 Januari 2019. P. 85-96.

6. http://www.foto-video.ru/art/postnie-misli

7. https://birdinflight.com/ru/vdohnovenie/fotoproect/20190806-microplastics-everyday.html 
8. Барт Р. Camera lucida. Комментарий к фотографии. М., 2011.

9. Новикова Я.А. ВИЗУАЛЬНЫЙ ПОВОРОТ В МЕДИА: ФЕНОМЕН ЖУРНАЛА «LIFE»http://www.tsutmb.ru/nauka/internet-konferencii/2019/ zhurnalistika/1/Novikova.pdf

10. Cognitive Ecology Handbook of Perception and Cognition (Second Edition) 1996, Pages 381-384

11. Environment and development Kenneth D. Kaunda Pages 1-9

12. Peter Brimblecombe, City and environment, City and Environment Interactions, Volume 1, 2019, 100005, ISSN $2590-2520$ https://doi.org/10.1016/j.cacint.2019.100005. http://www.sciencedirect.com/science/article/pii/S2590252019300054) 